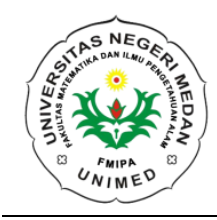

\author{
JURNAL EINSTEIN \\ Jurnal Hasil Penelitian Bindang Fisika \\ Available online http://jurnal.unimed.ac.id/2012/index.php/einsten \\ e-issn: $2407-747 x$, p-issn $2338-1981$
}

\title{
PENGONTROL GERBANG MENGGUNAKAN AUDIO DAN PEMANCAR RADIO FREKUENSI MICRO-WAVE BERBASIS ANDROID
}

\author{
R.Tinambunan ${ }^{1}$ dan R.A.Sani ${ }^{2}$ \\ Jurusan Fisika, Fakultas Matematika dan Ilmu Pengetahuan Alam, Universitas Negeri Medan, \\ Indonesia \\ randytinambunan@gmail.com
}

Diterima Februari 2018; Disetujui Februari 2018; Dipublikasikan Februari 2018

\begin{abstract}
ABSTRAK
Telah dilakukan penelitian pengontrol gerbang menggunakan audio dan pemancar radio dengan Arduino Mega2560 sebagai mikrokontroler dengan tujuan untuk membuat suatu alat pengontrol gerbang menjadi satu sistem pengontrolan yang dapat mengontrol buka tutup gerbang dengan mudah tanpa membutuhkan usaha lebih untuk membuka dan menutup gerbang. Dalam sistem pengontrol yang dirancang menggunakan mikrokontroler arduino mega2560, bluetooth HC-05, modul pemancar radio, smartphone, catu daya, motor driver L298, motor DC, sensor TCRT5000 dan LCD 16x2. Gerbang dikontrol menggunakan audio dan saklar buka tutup pada smartphone dan pemancar radio dengan menghubungkan keseluruhan rangkaian dengan alat pengontrol menjadi suatu sistem pengontrolan. Sensor TCRT5000 digunakan sebagai pengontrol gerbang untuk buka sebagian. Sensor dalam keadaan LOW (logika 0). Berdasarkan hasil pengujian sistem pengontrolan gerbang dengan smartphone android dan pemancar radio telah bekerja dengan baik. Karakteristik alat pengontrol gerbang dengan tiga kondisi yaitu buka penuh, buka sebagian dan tutup dengan menggunakan PWM (Pulse Width Modulation) sebesar 75 byte per sekon yang artinya duty cycle untuk motor DC yaitu $29,4 \% \approx 30 \%$. Untuk audio jarak maksimum yang dapat dikontrol yaitu $15 \mathrm{~m}$ dengan waktu maksimum untuk membuka dan menutup gerbang 6s. Untuk saklar buka tutup jarak maksimum yang dapat dikontrol yaitu $15 \mathrm{~m}$ dengan waktu maksimum untuk membuka dan menutup gerbang $4 \mathrm{~s}$. Untuk pemancar radio jarak maksimum yang dilakukan yaitu $30 \mathrm{~m}$ dengan waktu maksimum untuk membuka dan menutup gerbang 2,8 s.
\end{abstract}

Kata Kunci : Smartphone, Modul pemancar radio frekuensi, Sensor TCRT5000, Arduino Mega2560, Driver motor L298

\section{PENDAHULUAN}

Perkembangan teknologi yang semakin maju sangat memberikan kemudahan dan kenyamanan bagi manusia dalam melakukan setiap aktivitas. Salah satu usaha untuk memberikan kemudahan dan kenyamanan tersebut adalah melalui pengembangan sistem otomasi pada rumah (Home Automation), yaitu berupa sistem yang dapat membuka dan menutup pintu gerbang secara otomatis. Melalui pengembangan sistem ini diharapkan penghuni rumah dapat membuka dan menutup pintu gerbang dari jarak tertentu tanpa harus berinteraksi langsung dengan gerbang tersebut (Silvia, dkk.2014). 
Pintu gerbang menjadi hal yang paling disorot dalam ruang lingkup sistem keamanan rumah, hal tersebut karena fungsi pintu gerbang sebagai akses utama untuk masuk. Adanya pemasangan sistem keamanan pada pintu merupakan suatu bentuk otomatisasi sebagai dampak positif dari perkembangan teknologi. Dengan otomatisasi, maka dapat meringankan pekerjaan manusia karena sebagiannya digantikan oleh suatu alat atau mesin (Sumadikarta dan Setiyawan, 2017).

Salah satu kemudahan yang dimiliki oleh pintu gerbang ini adalah sistem kendali buka tutup pintu gerbang dengan menggunakan telepon genggam android, dengan menekan tombol ataupun perintah suara pada ponsel android, gerbang akan membuka sehingga pengguna tidak perlu untuk menarik dan mendorongnya karena ada mekanisme yang dipasangkan pada gerbang (Saifuddin dan Winardi, 2015). Sebagai salah satu contoh dari perkembangan teknologi yaitu pemanfaatan telepon genggam android yang dimanfaatkan sebagai alat pengontrol membuka dan menutup pintu gerbang, dengan adanya sistem ini dapat memudahkan dalam membuka dan menutup tanpa bersusah payah mendorong ataupun menarik pintu gerbang yang banyak menghabiskan waktu dan tenaga.

Penelitian yang dilakukan oleh Mohammad Rizal Saifuddin dan Slamet Winardi (2015) yaitu telah berhasil membuat model sistem buka tutup pintu pagar meggunakan mikrokontroler arduino uno. Alat sistem buka tutup pintu pagar dapat berjalan ketika menerima perintah dari smartphone android, motor dapat berputar ketika bluetooth alat dengan smartphone saling terkoneksi. Berdasarkan pengujian alat yang dirancang masih memiliki kekurangan yaitu pada saat kendali tutup pintu gerbang masih terjadi kesalahan pada sistem smartphone androidnya yaitu pada pengenalan suara tutup yang hampir mirip dengan kata youtube sehingga perlu dilakukan penelitian selanjutnya mengenai sistem aplikasi androidnya.

Penelitian yang dilakukan oleh Nahdia Raharjo dan M. Titon Jaya Putra (2017) yaitu telah berhasil membuat alat pengendali buka tutup pintu gerbang dan garasi menggunakan pemancar radio RF dan sensor infrared. Dengan menggunakan saklar pada remote control, maka membuka dan menutup pintu gerbang atau garasi dapat di kendalikan tanpa menarik atau mendorongnya. Sistem kerja alat ini menggunakan pemancar dan penerima radio $R F$ yang berfrekuensi $40 \mathrm{MHz}$, dengan mengirimkan pulsa-pulsa dengan menggunakan IC TX-2 T1143 sebagai pengirim sinyal pulsa dan IC RX-2 30905286 yang berjarak kurang dari 10 meter, akan tetapi masih perlu dilakukan penelitian selanjutnya untuk memperoleh jarak pengontrolan yang lebih jauh.

Berdasarkan uraian diatas penulis ingin melakukan penelitian yang berjudul "Pengontrol Gerbang Menggunakan Audio Dan Pemancar Radio Frekuensi Micro-Wave Berbasis Android", dimana dalam penelitian ini, peneliti menggunakan dua sistem pengontrolan yaitu pemancar radio frekuensi dan Audio dengan menggunakan frekuensi gelombang mikro 2,4 $\mathrm{GHz}$. Adapun sumber suara yang diperoleh saat memberikan perintah buka tutup gerbang adalah sumber suara pengguna ataupun pemakai.

\section{METODE PENLITIAN}

\section{Alat dan Bahan Penelitian}

Adapun alat dan bahan yang digunakan dalam penelitian ini adalah sebagai berikut :

Tabel 1. Alat Penelitian

\begin{tabular}{|c|c|c|c|}
\hline No & Nama Alat & Spesifikasi & Jumlah \\
\hline 1 & Multimeter & $\begin{array}{l}\text { Sunwa YX- } \\
\text { 360TRD }\end{array}$ & 1 buah \\
\hline 2 & Bor PCB & $\begin{array}{l}\text { Mata } 0.8 \mathrm{~mm} \\
\text { Mata } 1.0 \mathrm{~mm}\end{array}$ & 2 buah \\
\hline 3 & Solder & 30 Watt & 1 buah \\
\hline 4 & Komputer & $\begin{array}{l}\text { Acer Intel Core } \\
\text { i3 }\end{array}$ & 1 buah \\
\hline 5 & Adaptor & $12 \mathrm{~V} \mathrm{DC}$ & 1 buah \\
\hline 6 & Cutter & - & 1 buah \\
\hline 7 & Gunting & - & 1 buah \\
\hline 8 & Stopwatch & - & 1 buah \\
\hline 9 & Penyedot Timah & - & 1 buah \\
\hline 10 & $\begin{array}{l}\text { Downloader } \\
\text { Arduino IDE }\end{array}$ & IDE.1.6.5 & 1 unit \\
\hline
\end{tabular}

Tabel 2. Bahan Penelitian

\begin{tabular}{llll}
\hline No & Nama Bahan & Spesifikasi & Jumlah \\
\hline 1 & $\begin{array}{l}\text { Modul Arduino } \\
\text { Mega }\end{array}$ & 2560 & 1 Set \\
2 & Mikrokontroler & $\begin{array}{l}\text { ATMega } \\
2560\end{array}$ & 1 buah \\
& & \\
\hline
\end{tabular}




\begin{tabular}{|c|c|c|c|}
\hline 3 & Modul Bluetooth & HC-05 & 1 buah \\
\hline 4 & Motor DC & $5 \mathrm{~V}$ & 1 buah \\
\hline 5 & Driver Motor & L298 & 1 buah \\
\hline 6 & $\begin{array}{l}\text { Smartphone } \\
\text { Android }\end{array}$ & Oppo A37f & 1 buah \\
\hline 7 & $\begin{array}{l}\text { Modul pemancar } \\
\text { radio rf }\end{array}$ & $\begin{array}{l}\text { RX-TX } \\
443 \mathrm{MHz}\end{array}$ & 1 Set \\
\hline 8 & Sensor TCRT5000 & TCRT5000 & 1 buah \\
\hline 9 & Limit Switch & - & 2 buah \\
\hline 10 & Jumper & - & Secukupnya \\
\hline 11 & Timah & - & Secukupnya \\
\hline 12 & Kabel Pelangi & & Secukupnya \\
\hline 13 & LCD & $16 \times 2$ & 1 buah \\
\hline
\end{tabular}

\section{Prosedur Penelitian}

Adapun prosedur penelitian ini adalah sebagai berikut:

1. Menyiapkan alat dan bahan yang dibutuhkan dalam penelitian

2. Alat dan bahan yang diperlukan disiapkan dengan kondisi yang telah diuji.

3. Merangkai semua bagian-bagian rangkaian yang akan digunakan

4. Membuat list program Arduino kemudian mengdownloader kedalam mikrokontroler ATMega2560 dengan kabel USB yang telah tersedia pada PC.

5. Melakukan pengujian hasil rangkaian

6. Melakukan pengujian pada alat pengontrol yang dibuat apakah sudah bisa berfungsi dengan baik

7. Mengulangi prosedur 2 s/d 6 jika rangkaian tidak berfungsi dan bekerja secara efektif

8. Pengambilan data hasil uji rangkaian

9. Menarik kesimpulan

10. Membuat laporan penelitian.

\section{Perancangan Sistem Alat}

Perancangan sistem alat berfungsi untuk membantu dan mempermudah dalam mengerjakan alat yang akan dibuat. Perancangan alat dimulai dari pembuatan blok diagram dimana setiap blok tersebut mempunyai fungsi tersendiri yang saling berhubungan sehingga akan membentuk sistem yang akan dibuat.

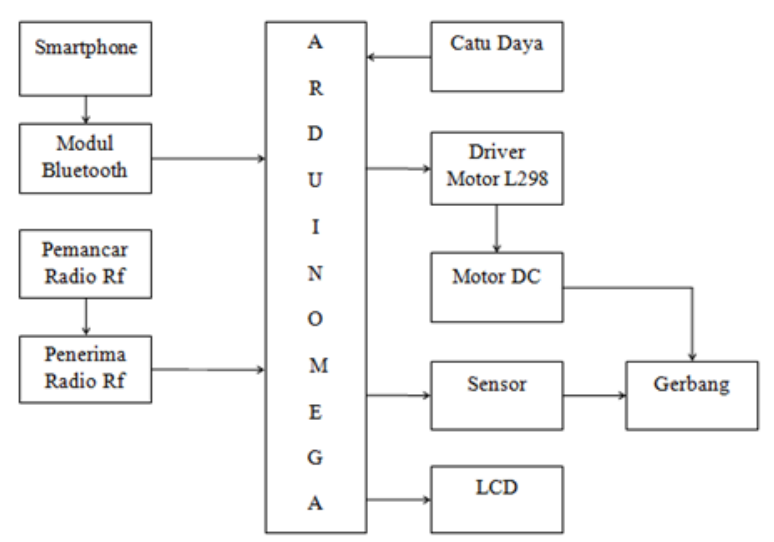

Gambar 1. Diagram Blok Rancangan Sistem

Keseluruhan

Fungsi dari blok diagram diatas yaitu:

1. Rangkaian catu daya berfungsi untuk men-supply tegangan keseluruh rangkaian alat

2. Board Arduino Mega2560 berfungsi mengolah dan mengontrol hasil pembacaan yang diterima dari smartphone dan pemancar radio $\mathrm{RF}$, sehingga dapat dihasilkan suatu informasi untuk membuka dan menutup gerbang yang ditampilkan pada LCD

3. Smartphone berfungsi sebagai input untuk mengirimkan perintah ke arduino melalui modul Bluetooth

4. Pemancar radio RF berfungsi untuk mentrasmisikan data ke penerima radio RF melalui gelombang radio yang dipancarkan oleh pemancar radio $\mathrm{RF}$

5. Penerima radio Rf berfungsi untuk mentransmisikan data ke mikrokontroler melalui gelombang radio yang diterima oleh penerima radio $\mathrm{RF}$

6. Modul bluetooth berfungsi untuk komunikasi serial wireless (nirkabel) yang mengkonversi port serial ke Bluetooth.

7. Driver motor L298 berfungsi sebagai driver motor DC yang menjalankan perintah dari mikrokontroler untuk mengontrol pergerakan dari motor ke kiri atau ke kanan dengan supply tegangan

8. Motor DC berfungsi mengubah tenaga listrik arus searah menjadi tenaga gerak berupa putaran dari pada motor 
9. Sensor TCRT5000 yaitu sensor pantulan yang digunakan untuk buka gerbang sebagian

10. LCD berfungsi untuk menampilkan data status dari pengontrolan gerbang.

\section{Perancangan Software}

Dalam pembuatan pemrograman mikrokontroler digunakan software yang dapat berfungsi sebagai pengeditan program. Dalam hal ini akan digunakan bahasa Arduino yang merupakan turunan dari bahasa C. Hasil pengeditan kemudian di-download kedalam chip mikrokontroler ATMega2560. Untuk penulisan program digunakan bahasa $\mathrm{C}$ Arduino.

\section{HASIL DAN PEMBAHASAN}

\section{Deskripsi Rancang Alat Pengontrol Gerbang}

Rancangan alat pengontrol gerbang ini dirancang menggunakan mikrokontroler arduino mega2560 yang digunakan sebagai sistem pengontrol dari alat yang dibuat, dimana hasil pengontrolan dari perintah yang telah diberikan akan ditampilkan pada Liquid Crystal Display. Semua komponen piranti tersebut telah selesai dirancang untuk dapat digunakan sebagai alat pengontrol gerbang. Adapun pengontrolan gerbang ini terdiri atas dua pengontrolan yaitu dengan menggunakan smarphone android dan pemancar radio frekuensi dengan tiga kondisi pengontrolan yaitu buka penuh, buka sebagian dan tutup. Smartphone android digunakan disini yaitu sebagai pengontrolan dengan perintah audio dan saklar buka tutup sedangkan pemancar radio frekuensi digunakan sebagai pengontrol dengan perintah berupa tombol. Pada smartphone aplikasi pengontrol gerbang di desain menggunakan aplikasi App Inventor yang disediakan oleh Google untuk membuat aplikasi perangkat lunak untuk sistem operasi android. Aplikasi ini memungkinkan setiap orang dapat membuat aplikasi yang digunakan pada android yang dihubungkan dengan bluetooth sehingga lewat android pengguna dapat mengirimkan perintah ke sistem pengontrol (Arduino). Untuk membuat aplikasi ini diperlukan suatu koneksi jaringan internet karena aplikasi di desain secara online melalui situs ai2.appinventor.mit.edu dan harus login terlebih dahulu menggunakan email.

\section{Pengujian Sistem}

Pengujian sistem bertujuan untuk mengetahui apakah sistem yang di rancang berfungsi dengan baik atau tidak, baik itu pengujian perangkat lunak maupun perangkat keras. Setelah dilakukan pengujian pada perangkat lunak dan perangkat keras, maka selanjutnya dilakukan pengujian keseluruhan sistem menjadi sebuah alat pengontrol gerbang. Pengujian keseluruhan sistem dilakukan untuk memastikan sistem pengontrol berfungsi dengan baik dan benar sesuai perintah.

\subsection{Pengujian Sistem Pengontrol Gerbang dengan Pemancar Radio RF}

Pengujian sistem pengontrolan gerbang ini dilakukan dengan mengirim perintah berupa data $A$, data $B$ dan data $C$ dengan menggunakan frekuensi $433 \mathrm{MHz}$, kemudian perintah berupa data A, data B dan data $\mathrm{C}$ akan dikirim ke receiver radio $\mathrm{RF}$ dengan frekuensi $433 \mathrm{MHz}$ yang selanjutnya akan diteruskan ke mikrokontroler arduino. Pada mikrokontroler arduino akan diproses perintah yang dikirim oleh pemancar radio RF kemudian diteruskan ke driver motor 1298 untuk menggerakkan motor DC kekiri atau kekanan dan pada sistem ini juga terdapat sensor TCRT5000 yang digunakan sebagai pengontrol gerbang untuk buka sebagian, dimana prinsip kerjanya yaitu ketika sensor dilewati sebuah benda yang dapat memantulkan cahaya maka sensor akan mendeteksi dan menangkap pantulannya maka gerbang akan berhenti dalam hal ini sensor dalam keadaan LOW (logika 0).

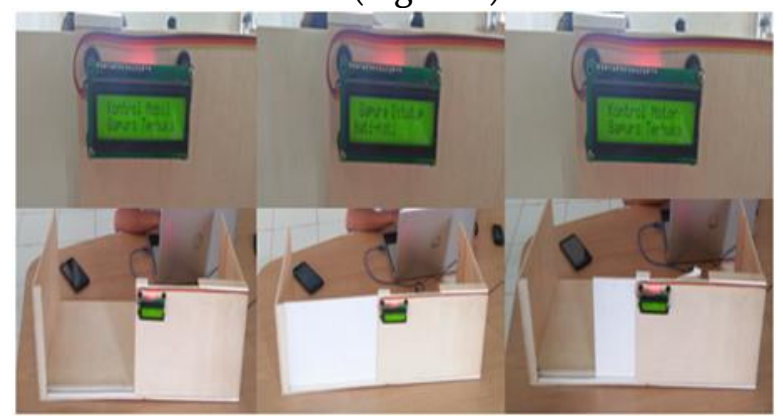

Gambar 2. Pengujian Pengontrol Gerbang dengan Pemancar Radio

Setelah dilakukan pengujian diperoleh hasil pengujian pengontrolan gerbang dengan pemancar radio frekuensi dibawah ini : 


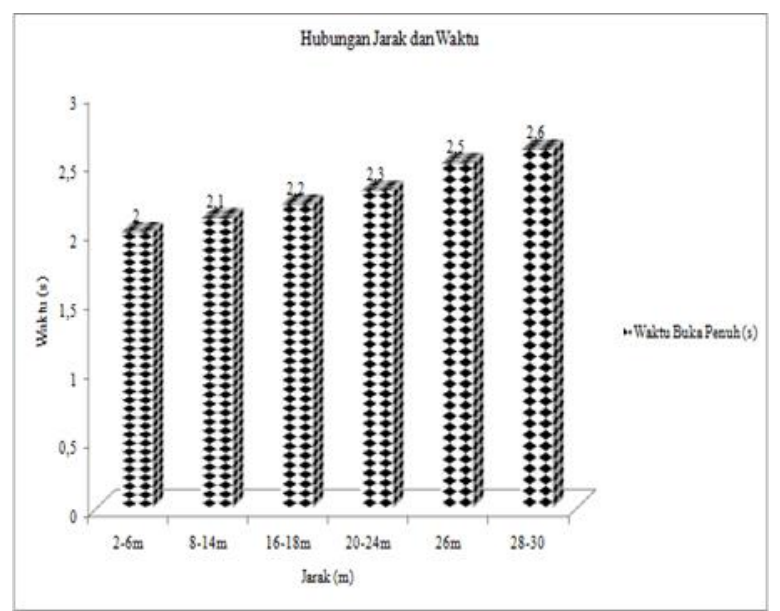

Gambar 3. Grafik Hubungan Jarak dan Waktu Buka Penuh pada Pemancar Radio

Dari Gambar 3 dapat diketahui hubungan antara jarak dan waktu buka penuh dari tiap pengontrolan yaitu bahwa semakin jauh jarak pengontrolan yang dilakukan maka semakin lama pula waktu yang dibutuhkan untuk membuka dan menutup gerbang. Jarak pengontrolan yang dilakukan untuk buka penuh yaitu 30. Pengontrolan dilakukan mulai jarak 2 meter dengan kenaikan 2 meter dari tiap pengontrolan. Untuk buka penuh pada jarak 2-6 meter waktu yang dibutuhkan yaitu 2 sekon. Pada jarak 8-14 meter waktu yang dibutuhkan 2,1 sekon. Pada jarak 16-18 meter waktu yang dibutuhkan 2,2 sekon. Pada jarak 20-24 meter waktu yang dibutuhkan 2,3 sekon. Pada jarak 26 meter waktu yang dibutuhkan 2,5 sekon dan pada jarak 28-30 meter waktu yang dibutuhkan 2,6 sekon.

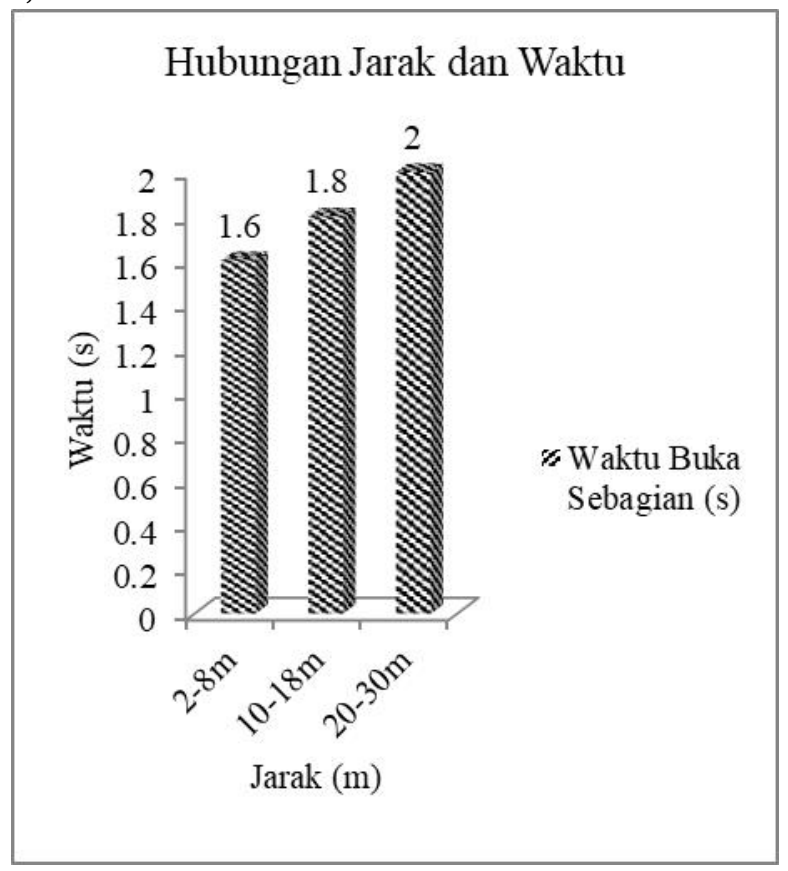

Gambar 4. Grafik Hubungan Jarak Dan Waktu Buka Sebagian Pada Pemancar Radio

Dari Gambar 4 dapat diketahui hubungan antara jarak dan waktu buka sebagian dari tiap pengontrolan yaitu bahwa semakin jauh jarak pengontrolan yang dilakukan maka semakin lama pula waktu yang dibutuhkan untuk membuka dan menutup gerbang. Jarak pengontrolan yang dilakukan untuk buka penuh yaitu 30. Pengontrolan dilakukan mulai jarak 2 meter dengan kenaikan 2 meter dari tiap pengontrolan. Untuk buka sebagian pada jarak 2-8 meter waktu yang dibutuhkan yaitu 1,6 sekon. Pada jarak 10-18 meter waktu yang dibutuhkan 1,8 sekon dan pada jarak 20-30 meter waktu yang dibutuhkan 2 sekon.

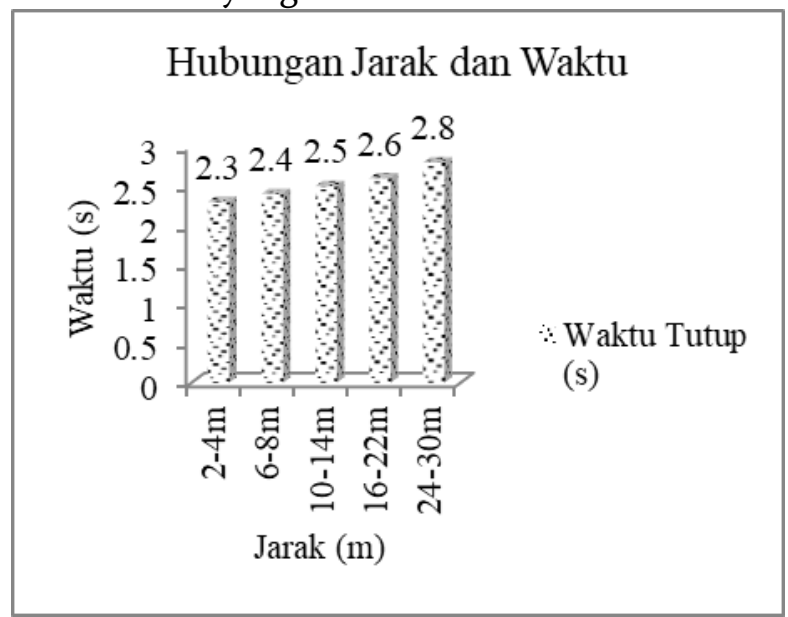

Gambar 5. Grafik Hubungan Jarak dan Waktu Tutup pada Pemancar Radio

Dari Gambar 5 dapat diketahui hubungan antara jarak dan waktu tutup dari tiap pengontrolan yaitu bahwa semakin jauh jarak pengontrolan yang dilakukan maka semakin lama pula waktu yang dibutuhkan untuk membuka dan menutup gerbang. Jarak pengontrolan yang dilakukan untuk buka penuh yaitu 30. Pengontrolan dilakukan mulai jarak 2 meter dengan kenaikan 2 meter dari tiap pengontrolan. Untuk nutup pada jarak 2-4 meter waktu yang dibutuhkan 2,3 sekon. Pada jarak 68 meter waktu yang dibutuhkan 2,4 sekon. Pada jarak 10-14 meter waktu yang dibutuhkan 2,5 sekon. Pada jarak 16-22 meter waktu yang dibutuhkan 2,6 sekon dan pada jarak 24-30 meter waktu yang dibutuhkan 2,8 sekon. 


\subsection{Pengujian Sistem Pengontrol Gerbang dengan} Audio

Pengujian sistem ini dilakukan dengan mengaktifkan bluetooth pada smartphone android telebih dahulu, selanjutnya buka aplikasi yang telah dibangun pada smartphone android, kemudian masukkan user dan password yang telah diatur pada aplikasi selanjutnya tekan submit untuk mulai masuk ke aplikasi pengontrol, pada aplikasi ini akan tampak menu utama yang terdiri dari menu suara (audio) dan menu buka tutup sebagai aplikasi pengontrol gerbang. Untuk memulai pengontrolan dengan suara yaitu dengan menekan tombol menu suara berupa mikrofon terlebih dahulu, setelah tampil selanjutnya dengan mengaktifkan bluetooth terlebih dahulu yaitu dengan menekan tombol bluetooh pada aplikasi yang selanjutnya pilih pairing bluetooth dalam hal ini "bluetooth $\mathrm{HC}$ 05”, setelah terhubung selanjutnya dengan menekan tombol suara berupa mikrofon kemudian kita ucapkan perintah yang telah disesuaikan pada program arduino maka gerbang akan terbuka dan tertutup dan pada sistem ini juga terdapat sensor TCRT5000 yang digunakan sebagai pengontrol gerbang untuk buka sebagian, dimana prinsip kerjanya yaitu ketika sensor dilewati sebuah benda yang dapat memantulkan cahaya maka sensor akan mendeteksi dan menangkap pantulannya maka gerbang akan berhenti dalam hal ini sensor dalam keadaan LOW (logika 0). Adapun perintah suara yang telah disesuaikan pada pemograman arduino untuk pengontrolan gerbang yaitu buka gapura kanggo mobil, buka gapura kanggo motor dan nutup gapura.

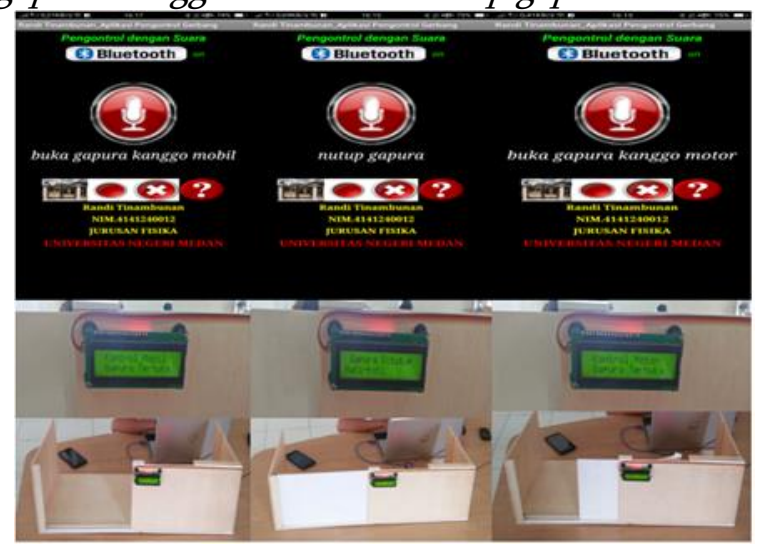

Gambar 6. Pengujian Pengontrol Gerbang dengan Audio
Setelah dilakukan pengujian diperoleh hasil pengujian pengontrolan gerbang dengan audio dibawah ini :

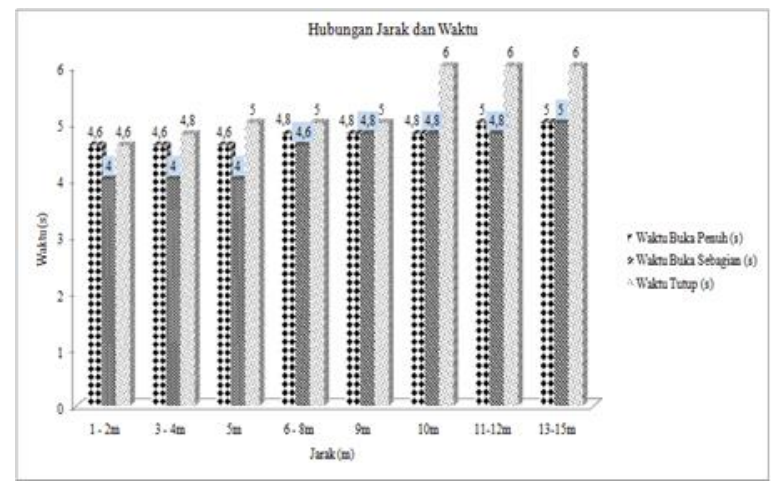

Gambar 7. Grafik Hubungan Jarak dan Waktu pada Audio

\subsection{Pengujian Sistem Pengontrol Gerbang dengan Saklar Buka Tutup pada Android}

Pengujian sistem ini dilakukan dengan mengaktifkan bluetooth pada smartphone android telebih dahulu, selanjutnya buka aplikasi yang telah dibangun pada smartphone android, kemudian masukkan user dan password yang telah diatur pada aplikasi selanjutnya tekan submit untuk mulai masuk ke aplikasi pengontrol, pada aplikasi ini akan tampak menu utama yang terdiri dari menu suara (audio) dan menu buka tutup sebagai aplikasi pengontrol gerbang. Untuk memulai pengontrolan dengan saklar buka tutup yaitu dengan menekan tombol buka tutup terlebih dahulu, setelah tampil selanjutnya yaitu dengan menekan tombol bluetooh pada aplikasi yang selanjutnya pilih pairing bluetooth dalam hal ini "bluetooth $\mathrm{HC}$ 05", setelah terhubung selanjutnya dengan menekan tombol1, tombol2 dan tombol tutup maka gerbang akan terbuka dan tertutup dan pada sistem ini juga terdapat sensor TCRT5000 yang digunakan sebagai pengontrol gerbang untuk buka sebagian, dimana prinsip kerjanya yaitu ketika sensor dilewati sebuah benda yang dapat memantulkan cahaya maka sensor akan mendeteksi dan menangkap pantulannya maka gerbang akan berhenti dalam hal ini sensor dalam keadaan $L O W($ logika 0$)$. 


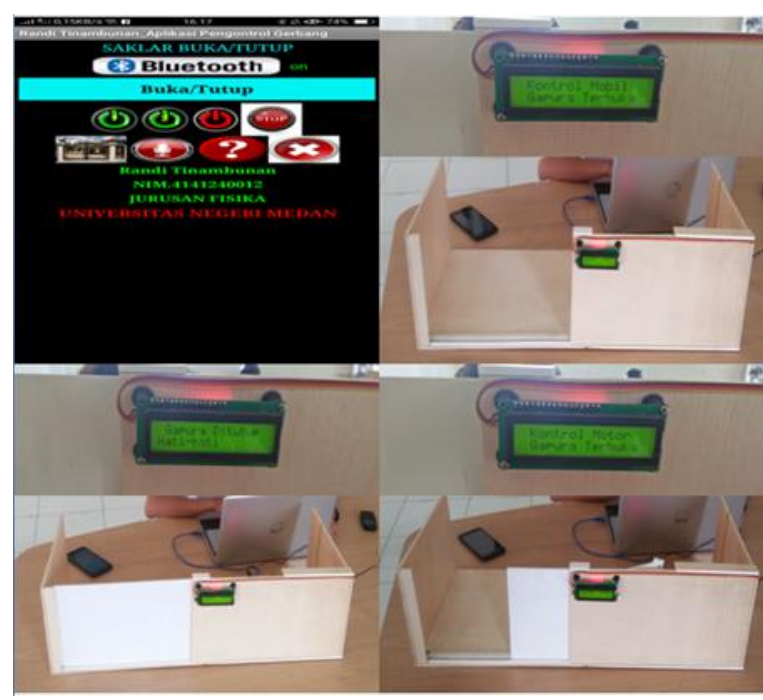

Gambar 8. Pengujian Pengontrol Gerbang dengan Saklar Buka Tutup pada Android

Setelah dilakukan pengujian diperoleh hasil pengujian pengontrolan gerbang dengan saklar buka tutup pada android dibawah ini :

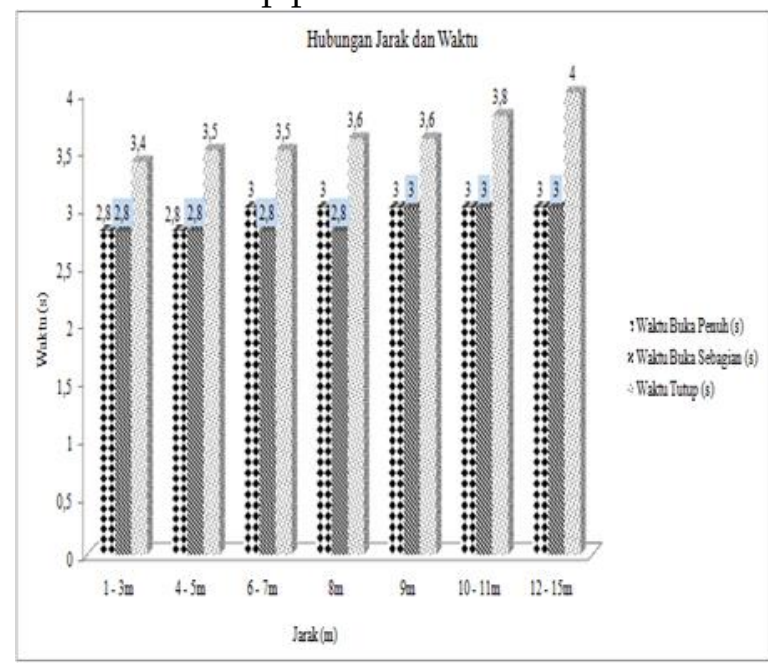

Gambar 9. Grafik Hubungan antara Jarak dan Waktu pada saklar Buka Tutup pada Android

Dari Gambar 9 dapat diketahui hubungan antara jarak dan waktu dari tiap pengontrolan yaitu bahwa semakin jauh jarak pengontrolan yang dilakukan maka semakin lama pula waktu yang dibutuhkan untuk membuka dan menutup gerbang. Adapun kondisi pengontrolan gerbang yang dilakukan yaitu buka penuh, buka sebagian dan tutup. Jarak maksimum pengontrolan yang diperoleh untuk buka penuh, buka sebagian dan nutup yaitu 15 meter. Untuk buka penuh pada jarak 15 meter waktu yang dibutuhkan 2,8 sekon dan pada jarak 6-15 meter waktu yang dibutuhkan 3 sekon. Untuk buka sebagian pada jarak 1-8 meter waktu yang dibutuhkan 2,8 sekon dan pada jarak 9-15 meter waktu yang dibutuhkan 3 sekon. Untuk nutup pada jarak 1-3 meter waktu yang dibutuhkan 3,4 sekon. Pada jarak 4-7 meter waktu yang dibutuhkan 3,5 sekon. Pada jarak 8-9 meter waktu yang dibutuhkan 3,6 sekon. Pada jarak 10-11 meter waktu yang dibutuhkan 3,8 sekon dan pada jarak 12-15 meter waktu yng dibutuhkan 4 sekon.

Pengukuran tegangan dan arus dilakukan yaitu untuk mengetahui besarnya daya yang dibutuhkan untuk mengontrol motor DC dari tiap pengontrolan yaitu dengan mengukur besarnya tegangan dan arus output pada driver motor L298 yang digunakan untuk memutar motor DC. Pengukuran dilakukan dengan menggunakan multimeter yaitu dengan menghubungkan probe positif dan negatif pada multimeter ke output driver motor L298, dimana pengukuran dilakukan pada saat pengontrolan gerbang dilakukan. Berikut dibawah ini hasil pengukuran tegangan dan arus yang dibutuhkan untuk memutar motor DC dari tiap pengontrolan yaitu :

Tabel 3. Hasil pengukuran tegangan dan arus output pada driver motor 1298 yang digunakan untuk memutar motor DC pada pengontrolan gerbang dengan radio pemancar

\begin{tabular}{|c|l|c|c|c|c|}
\hline \multirow{2}{*}{ No } & \multirow{2}{*}{ Pengukuran } & \multicolumn{2}{|c|}{ Tegangan (V) } & \multicolumn{2}{c|}{ Arus (mA) } \\
\cline { 3 - 6 } & Input & Output & Input & Output \\
\hline 1 & Buka penuh & 5 & 3 & 0,36 & 0,3 \\
\hline 2 & $\begin{array}{l}\text { Buka } \\
\text { sebagian }\end{array}$ & 5 & 3 & 0,36 & 0,3 \\
\hline 3 & Tutup & 5 & 3 & 0,36 & 0,3 \\
\hline
\end{tabular}

Tabel 4. Hasil pengukuran tegangan dan arus output pada driver motor 1298 yang digunakan untuk memutar motor DC pada pengontrolan gerbang dengan audio

\begin{tabular}{|c|l|c|c|c|c|}
\hline \multirow{2}{*}{ No } & \multirow{2}{*}{ Pengukuran } & \multicolumn{2}{|c|}{ Tegangan (V) } & \multicolumn{2}{c|}{ Arus (mA) } \\
\cline { 3 - 6 } & Input & Output & Input & Output \\
\hline 1 & Buka penuh & 5 & 3 & 0,36 & 0,3 \\
\hline 2 & $\begin{array}{l}\text { Buka } \\
\text { sebagian }\end{array}$ & 5 & 3 & 0,36 & 0,3 \\
\hline 3 & Tutup & 5 & 3 & 0,36 & 0,3 \\
\hline
\end{tabular}

Tabel 5. Hasil pengukuran tegangan dan arus output pada driver motor 1298 yang digunakan untuk memutar motor DC pada pengontrolan gerbang dengan saklar buka-tutup pada android 


\begin{tabular}{|c|l|c|c|c|c|}
\hline \multirow{2}{*}{ No } & \multirow{2}{*}{ Pengukuran } & \multicolumn{2}{|c|}{ Tegangan (V) } & \multicolumn{2}{c|}{ Arus (mA) } \\
\cline { 3 - 6 } & & Input & Output & Input & Output \\
\hline 1 & Buka penuh & 5 & 3 & 0,36 & 0,3 \\
\hline 2 & $\begin{array}{l}\text { Buka } \\
\text { sebagian }\end{array}$ & 5 & 3 & 0,36 & 0,3 \\
\hline 3 & Tutup & 5 & 3 & 0,36 & 0,3 \\
\hline
\end{tabular}

Dari tabel diatas dapat diketahui besarnya arus dan tegangan yang dibutuhkan untuk mengontrol gerbang dari tiap pengontrolan yaitu $0,3 \mathrm{~mA}$ dan $3 \mathrm{~V}$, sehingga diperoleh besarnya daya yang dibutuhkan untuk mengontrol motor DC yaitu 0,0009 watt.

\section{Pembahasan}

Berdasarkan data hasil penelitian, didapatkan bahwa rancangan alat pengontrol gerbang menggunakan mikrokontroler arduino mega2560 yang digunakan sebagai sistem pengontrol dari alat yang dibuat dapat berjalan dan berfungsi dengan baik, dimana hasil pengontrolan dari perintah yang telah diberikan akan ditampilkan pada Liquid Crystal Display. Semua komponen piranti tersebut telah selesai dirancang untuk dapat digunakan sebagai alat pengontrol gerbang. Adapun pengontrolan gerbang ini terdiri atas dua pengontrolan yaitu dengan menggunakan smartphone android dan pemancar radio dengan tiga kondisi pengontrolan yaitu buka penuh, buka sebagian dan tutup. Smartphone android digunakan disini yaitu sebagai pengontrolan dengan perintah audio berupa buka gapura kanggo mobil, buka gapura kanggo motor, nutup gapura dan saklar buka tutup, dimana pada proses pengiriman perintah audio menggunakan frekuensi yang ada pada bluetooth yaitu 2,4 $\mathrm{GHz}$ sedangkan pemancar radio digunakan sebagai pengontrol dengan perintah berupa tombol dengan menggunakan frekuensi $433 \mathrm{MHz}$. Perintah tersebut dikirim dengan cara menumpangkan perintah pada sinyal gelombang radio frekuensi yang kemudian diteruskan ke mikrokontroler arduino mega2560 untuk diproses menjadi sebuah perintah yang akan diteruskan ke driver motor L298 untuk menggerakkan motor DC, selanjutnya gerbang akan terbuka atau tertutup sesuai perintah yang diberikan. Pada sistem ini juga digunakan sensor TCRT5000 yang digunakan sebagai pengontrol gerbang untuk buka sebagian, dimana prinsip kerjanya yaitu ketika sensor dilewati sebuah benda yang dapat memantulkan cahaya maka sensor akan mendeteksi dan menangkap pantulannya maka gerbang akan berhenti dalam hal ini sensor dalam keadaan $L O W($ logika 0$)$.

Adapun untuk pengaturan kecepatan motor DC yaitu menggunakan PWM (Pulse Width Modulation) yaitu suatu sinyal yang dikirim dengan frekuensi tetap namun memiliki panjang pulsa yang berbeda-beda dalam setiap periodenya. Perbedaan ini disebut dengan duty cycle yaitu perbandingan lama pulsa dengan keseluruhan periode sinyal. Duty cycle juga merupakan representasi dari kondisi logika high dalam suatu periode sinyal yang dapat dinyatakan dalam bentuk persen (\%) dengan range $0 \%-100 \%$. Dalam penelitian ini digunakan PWM sebesar 75 byte per sekon artinya lebar pulsa yang digunakan dalam pengontrolan gerbang sebesar 75 byte per sekon, dimana pada penggunaan PWM lebar pulsa maksimum yang digunakan untuk mengatur kecepatan motor DC yaitu 255 byte per sekon, sehingga dapat diperoleh duty cycle untuk motor DC yaitu $29,4 \% \approx 30 \%$

Pada pengujian pengontrol gerbang dengan pemancar radio, audio dan saklar buka tutup diperoleh bahwa sistem pengontrolan gerbang telah bekerja dengan baik dan sesuai dengan yang diharapkan yaitu buka penuh, buka sebagian dan tutup. Besarnya daya yang dibutuhkan dari tiap pengontrolan gerbang yaitu 0,0009 watt yang digunakan sebagai daya pada motor DC. Pada pemancar radio pengujian buka tutup gerbang dilakukan dengan jarak maksimal yaitu 30 meter, dengan waktu maksimum yang dibutuhkan untuk membuka gerbang penuh 2,6 sekon, membuka gerbang sebagian 2 sekon dan menutup gerbang 2,8 sekon. Pada pengujian pengontrol gerbang dengan audio diperoleh bahwa jarak maksimum pengontrolan untuk buka penuh, buka sebagian dan nutup yaitu 15 meter, dengan waktu maksimum yang dibutuhkan untuk membuka gerbang penuh dan sebagian 5 sekon dan menutup gerbang 6 sekon. Pada pengujian pengontrol gerbang dengan saklar buka tutup pada android diperoleh bahwa jarak 
maksimum pengontrolan untuk buka penuh, buka sebagian dan nutup yaitu 15 meter, dengan waktu maksimum yang dibutuhkan untuk membuka gerbang penuh dan sebagian 3 sekon dan menutup gerbang 4 sekon. Adapun hasil dari tiap pengontrolan akan ditampilkan di LCD. Adanya perbedaan waktu respon dari tiap pengontrolan gerbang yang dilakukan yaitu samakin jauh jarak pengontrolan yang dilakukan maka semakin lama waktu yang dibutuhkan untuk mengontrol gerbag. Hal ini terjadi karena pada pengiriman perintah melalui modul bluetooth dan modul pemancar radio yaitu terdapat sinyal gelombang elektromagnetik yang dikirim oleh pemancar melalui udara dengan cara menumpangkan perintah pada sinyal radio frekuensi dan selanjutnya akan diterima oleh si penerima, dimana pada proses pengiriman perintah melalui udara terjadi perambatan energi, sehingga energi berkurang dan waktu yang dibutuhkan untuk pengiriman bertambah karena tidak langsung diterima oleh receiver.

\section{KESIMPULAN DAN SARAN}

Setelah dilakukan penelitian mengenai pengontrolan gerbang menggunakan audio dan pemancar radio dapat disimpulkan bahwa:

1. Pengontrolan gerbang dengan audio dan pemancar radio telah bekerja dengan baik. Karakteristik alat pengontrol gerbang dengan tiga kondisi diantaranya buka penuh, buka sebagian dan tutup dengan menggunakan PWM (Pulse Width Modulation) sebesar 75 byte per sekon yang artinya duty cycle untuk motor DC yaitu $29,4 \% \approx 30 \%$. Untuk audio jarak maksimum yang dapat dikontrol yaitu $15 \mathrm{~m}$ dengan waktu maksimum untuk membuka dan menutup gerbang 6s. Untuk saklar buka tutup pada android jarak maksimum yang dapat dikontrol yaitu $15 \mathrm{~m}$ dengan waktu maksimum untuk membuka dan menutup gerbang 4s. Untuk pemancar radio jarak maksimum yang dilakukan yaitu 30m dengan waktu maksimum untuk membuka dan menutup gerbang 2,8 sekon.
2. Algoritma efektif untuk sistem kontrol gerbang menggunakan audio dan pemancar radio frekuensi micro-wave telah berjalan sesuai dengan perintah yang diberikan yaitu buka gapura kanggo mobil, T1, data A; buka gapura kanggo motor, T2, data B dan nutup gapura, T3, data C dimana algoritma sistem pengontrol gerbangnya dapat bekerja sesuai dengan tahapan maupun intruksi yang telah diberikan.

Berdasarkan hasil penelitian pengontrol gerbang menggunakan audio dan pemancar radio, maka penulis memberikan saran agar alat ini dapat dikembangkan lagi menjadi lebih baik, yaitu: untuk penelitian selanjutnya, sebaiknya menggunakan jaringan internet berupa wifi untuk pengontrolan gerbang agar jarak dari pengontrolan yang didapatkan semakin jauh.

\section{DAFTAR PUSTAKA}

Raharjo, N., dan Putra, M.T.J., (2017), Simulasi Alat Pengendali Otomatis Pintu Gerbang dan Garasi Menggunakan Pemancar Radio RF dan Sensor IR, Jurnal JE-Unisla2(1): 2502-0986

Saifuddin, M.R., dan Winardi, S., (2015), Pintu Pagar Otomatis dengan Kontrol Suara Berbasis Smartphone Android, Jurnal Link 22(1): 1858-4667

Silvia, A.F., Haritman, E., dan Muladi,Y., (2014),Rancang Bangun Aksese Kontrol Pintu Gerbang Berbasis Arduino dan Android, Electrans 13(1): 1412-3762

Sumadikarta, I., dan Setiyawan, E.P., (2017), Rancang Bangun Prototype Kendali Pintu Gerbang Menggunakan Mikrokontroler Atmega 2560, Prosiding Mei 2017 